\title{
EquiLIBRIUM
}

Quarterly Journal of Economics and Economic Policy

2016 VOLUME 11 ISSUE 4, December

p-ISSN 1689-765X, e-ISSN 2353-3293

www.economic-policy.pl

Hybka, M. M. (2016). Allocating Tax Revenue to Sub-Central Government Levels: Lessons from Germany and Poland. Equilibrium. Quarterly Journal of Economics and Economic Policy, 11(4), 689-

709. DOI: http://dx.doi.org/10.12775/EQUIL.2016.031

Małgorzata Magdalena Hybka *

Uniwersytet Ekonomiczny w Poznaniu, Poland

\section{Allocating Tax Revenue to Sub-Central Government Levels: Lessons from Germany and Poland}

JEL Classification: $H 2 ; H 7$

Keywords: apportionment of tax revenue; fiscal federalism; Germany; Poland

\begin{abstract}
Tax sharing arrangements provide considerable financial resources to sub-central government levels. This statement is true both for unitary and federal states although tax revenue sharing mechanisms differ significantly across countries. The basic aim of this article is to compare the mechanisms adopted in Germany and in Poland. It assesses the degree of tax autonomy granted to sub-central government levels in the countries analysed, overviews the principles of apportionment of joint (shared) taxes and presents statistics on tax revenue composition of sub-central government levels.
\end{abstract}

\section{Introduction}

Over the last few decades, the theory of fiscal federalism has attracted a lot of scientists' attention. According to this theory, if there are no economies of scale then a decentralized pattern of public outputs reflecting differences in tastes across jurisdictions is welfare enhancing as compared to centralized outcome (Oates, 2008, p. 314). In order to cover expenditures related to the fulfillment of decentralized functions the sub-central government

(C) Copyright Institute of Economic Research

Date of submission: March 30, 2015; date of acceptance: June 14, 2016

* Contact: malgorzata.hybka@ue.poznan.pl, Uniwersytet Ekonomiczny w Poznaniu, al Niepodległości 10, 61-875 Poznań 
units require sufficient financial resources. In the case of a restricted fiscal autonomy of these units, the financing of their public tasks in a decentralized system is based mainly on a mechanism of transfers from the central (federal) government.

One of the main components of the fiscal autonomy of each government level is therefore taxing power. The term taxing power (or tax autonomy) captures the extent of freedom sub-central governments exert over tax policy (Blöchliger \& Nettley, 2015, p. 3). Governments may have three types of competences: in terms of tax legislation, in terms of tax revenue and in terms of tax administration. The decentralization of these competences may occur in various ways. For instance, the central government may be responsible for tax legislation and tax administration, however tax revenue may be apportioned between different levels of government or in a more decentralized system local government may be entitled to set their own tax rates, to impose a surtax on a central (federal) tax liability or even to choose its own tax base, at least within the limits allowed for by a common tax administration system (Boadway \& Shah, 2009, pp. 86-87).

The basic aim of this article is to compare the tax autonomy of subcentral government levels and tax sharing arrangements between different government levels in Germany and in Poland. Although Poland is classified as a unitary state, certain public responsibilities and competences are transferred to lower-levels of government. As a result, Poland may be considered as more fiscally decentralized than some federal countries. Germany, on the other hand, is a cooperative federation, in which, for the majority of policy areas, the federal government sets the policy framework and the states are responsible for its implementation (Kedar, 2009, p. 172). The tariffs of all the fiscally important taxes (joint taxes) are set by the federal government, a uniform tax tariff applies in all German states, and the enforcement of the tax law is delegated to the states (Bönke et al., 2013, p. 2). There are significant differences in the scale of federal influence on subnational governments between federal countries. Germany is amongst the countries where this scale is relatively large and the influence exercised on local governments is strong.

\section{Research Methodology}

This article attempts to compare the taxing power of the public finance subsectors (different government levels) and the tax revenue sharing procedures in two European states which differ extensively with respect to the extent of decentralisation of the public finance sector, i.e. Germany and 
Poland. It distinguishes three categories of taxing power: power with respect to making tax law, power with respect to obtaining tax revenue and power with respect to managing tax collection (administering taxes). The degree of financial autonomy of a sub-central government unit depends mostly on the two first categories. Therefore, they are the ones the article discusses the most thoroughly.

The methodology of this article is determined by the research topic and the research objectives. The scope of taxing power is specified in the legislation applicable in each of the two countries analysed. Hence, the first part of this article includes a legislative analysis of the regulations comprised in selected national acts. It focuses on provisions included in the Constitutions of both countries, acts specifying the sources of financing for local selfgovernment units and defining principles according to which the tax revenues are shared. The relevant legislation is presented as of 31st December 2014. The first part of this article, also reviews Polish and foreign literature on the topic analysed, along with the publications of the German Federal Ministry of Finance (Bundesministerium der Finanzen).

The second part of this article contains the analysis of statistical data with regard to the tax and public revenue sources. It takes into account the years 2009-2013. This time span of the analysis may be explained by the availability of statistical data. This part includes the presentation of the structure of tax revenues by the public finance subsectors in Germany and Poland, and a comparison of these structure in both countries. The share of different public finance subsector's in the joint tax revenues and in the total tax revenues of the public finance sector are calculated along with the percentage rate of the joint tax revenues in the total tax revenues and the share of the tax revenues in the total budgetary revenues for each subsector level. The statistical data used for these calculations come from the publications of the Supreme Audit Office (NIK) in Poland, the Central Statistical Office of Poland (GUS), the German Federal Ministry of Finance (Bundesministerium der Finanzen) and the Federal Statistical Office of Germany (Statistisches Bundesamt Deutschland).

\section{Tax Autonomy of Federal, State and Municipal Governments in Germany}

In Germany, one of the most important legal acts regulating the taxing powers of the Federation (Bund), the states (Länder) and the municipalities (Gemeinden) is the Constitution. The broadest competences to make taxation law are those of the federal government, which has the exclusive legis- 
lative power (ausschließliche Gesetzgebung) and concurrent legislative power (konkurrierende Gesetzgebung). Article 105 (1) of the German Constitution (Grundgesetz vom 23 Mai 1949) gives the Federation the exclusive power to legislate with respect to customs duties and fiscal monopolies. Taxes other than fiscal monopolies are regulated by the concurrent legislation. The Federation has the right to legislate taxes when the whole or the part of the revenue is allocated to the Federation or if the establishment of equal living conditions throughout the federal territory or the maintenance of legal or economic unity makes federal regulation necessary in the national interest. This means that with respect to other taxes, the states have the power to legislate as long as the Federation has not exercised its legislative power. In compliance with the provisions of Article 105 (2a) of the Constitution, the states have the power to legislate local taxes on consumption and expenditures as long as they are not substantially similar to taxes imposed by federal law. Moreover, the states have the power to specify the rates of the tax on the acquisition of immovable property (Grunderwerbsteuer). The municipalities (Gemeinden) do not have legislative powers, only the right to apply multipliers (Hebesätze) on the trade tax (Gewerbesteuer) and the real estate tax (Grundsteuer) within the limits specified by federal law. Legislation concerning other local taxes not regulated in federal acts of law is regulated in acts adopted by particular states.

In Germany there is a distinction between the vertical (vertikale Steuerverteilung) and horizontal system of tax revenue distribution (horizontale Steuerverteilung). The aim of the vertical system is to divide the revenues within the federation - amongst states, municipalities or unions of municipalities. It involves ascribing whole revenues from certain kinds of taxes to the federation, states and municipalities and proportional shares in the so-called shared (joint) taxes. The horizontal system of tax revenue distribution means the redistribution of these resources amongst units belonging to the same public finance subsector.

The rights with respect to obtaining tax revenues are regulated in Articles 106, 106a, 106b and 107 of the Constitution. On this basis, the revenue from the following taxes is allocated to the Federation: excise on spirits (Branntweinsteuer), sparkling wines (Schaumweinsteuer), intermediate products (Zwischenerzeugnissteuer), sweet beverages containing alcohol, i.e. alkopops (Alkopopsteuer); tobacco tax (Tabaksteuer), energy tax (Energiesteuer), coffee tax (Kaffeesteuer), insurance tax (Versicherungsteuer), electricity tax (Stromsteuer), nuclear fuel tax (Kernbrennstoffsteuer), and air passenger tax (Luftverkehrsteuer). Apart from that the Federation receives tax revenues from the road haulage tax (Straßengüterverkehrsteuer), the motor vehicle tax (Kraftfahrzeugsteuer), and other kinds of taxes on 
transactions related to motorised means of transport, one-time capital and compensation levies, subsidiary levies on personal and corporate income taxes, e.g. the solidarity surcharge (Solidaritätszuschlag), and levies imposed due to the membership in the European Union. The next group of taxes are those which are allocated entirely to the states; these include: the inheritance and gift tax (Erbschaftsteuer/Schenkungsteuer), tax on the acquisition of immovable property (Grunderwerbsteuer), fire protection tax (Feuerschutzsteuer), betting and lottery tax (Rennwett- und Lotteriesteuer), beer tax (Biersteuer) and gaming casinos levy (Abgabe von Spielbanken). As far as municipalities and unions are concerned, they receive tax revenues from the following taxes: the real estate tax (Grundsteuer), dog tax (Hundesteuer), beverage tax (Getränkesteuer), hunting and fishing tax (Jagd- und Fischereisteuer), trade tax (Gewerbesteuer), secondary residence tax (Zweitwohnungsteuer), entertainment tax (Vergnügungsteuer), licensing tax on the sale of beverages (Schankerlaubnissteuer), and packaging tax (Verpackungsteuer).

The most important taxes in the German tax system are shared taxes. Revenues from these taxes are divided between the Federation, the states and the municipalities. They include: the assessed income tax (veranlagte Einkommensteuer), wage withholding tax (Lohnsteuer), withholding tax on capital gains (Abgeltungsteuer), other withheld income taxes (nicht veranlagte Steuern von Ertrag), corporate income tax (Körperschaftsteuer), and value added tax (Umsatzsteuer). The statutory share of the Federation, the states and municipalities in the revenue from the shared taxes is presented in Table 1.

Table 1. Statutory share of Federation, states and municipalities in revenues from shared taxes in Germany

\begin{tabular}{lccc}
\hline \multicolumn{1}{c}{ Type of tax } & \multicolumn{3}{c}{ Share in \% } \\
\cline { 2 - 4 } & $\begin{array}{c}\text { Federation } \\
(\text { Bund })\end{array}$ & $\begin{array}{c}\text { States } \\
(\text { Länder })\end{array}$ & $\begin{array}{c}\text { Municipalities } \\
(\text { Gemeiden })\end{array}$ \\
\hline Assessed income tax; Wage withholding tax & 42.50 & 42.50 & 15.00 \\
\hline Withholding tax on capital gains & 44.00 & 44.00 & 12.00 \\
\hline Other withheld income taxes & 50.00 & 50.00 & - \\
\hline Corporate income tax & 50.00 & 50.00 & - \\
\hline Value added tax & 53.47 & 44.53 & 2.00 \\
\hline
\end{tabular}

Source: Das bundesstaatliche Finanzausgleich (2014, p. 3). 
Competences with respect to tax administration are regulated by Article 108 of the Constitution and the Tax Administration Act (Finanzverwaltungsgesetz vom 30. August 1971). The law grants the federal government authorities competences to administer duties, fiscal monopolies and consumption taxes where the principles concerning their collection are specified in federal acts; these levies include VAT on imported goods and other taxes on transactions related to motorised means of transport, collected since 1st July 2009, as well as taxes collected in relation to the European Communities.

The remaining taxes are administered by the fiscal authorities of the states. The only exceptions are taxes where the revenue is allocated entirely or partially to the Federation. In compliance with Article 108 (3) of the Constitution, these levies are administered by the states on behalf of the Federation. The states are free to choose the organisation of their administration and the only rule to follow when organising the administration is the principle of uniform taxation in compliance with the law (Ulbricht, 2008, p. 198).

The statutory share in revenues from the shared taxes allocated to the states is divided amongst them in accordance with a statutory key. With respect to income taxes, the principle of residence is taken into account. Thus, a state is given the income tax paid by a taxpayer if the taxpayer lives in this state or - in the case of corporations - if the corporation's management board is located in this state ( $\$ 1$ (1) Zerlegungsgesetz vom 6. August 1998). As a result the distribution of the revenues depends on the amount of tax revenues generated by a given state. In the case of the distribution of revenues from value added tax, the rules are different: as much as $75 \%$ of the revenue from VAT to which the states are entitled is distributed on the basis of the number of inhabitants of the relevant states. The remaining $25 \%$ is a subsidy which is divided depending on the so-called fiscal performance index (Steuerkraft). Calculating the fiscal performance index involves taking into account the share of a particular state in the revenues from the assessed income tax, wage withholding tax, withholding tax on capital gains, other withheld income taxes, corporate income tax, trade tax and the revenues of these states from the remaining taxes per inhabitant. A state is entitled to a subsidy if this index is lower than the average calculated for all the states $(\S 2$ (1) Finanzausgleichgesetz vom 20. Dezember 2001).

Both the Federation and the states are entitled to a share in the trade tax. Municipalities are obliged to transfer a share of the tax revenues from that tax to the Federation and the states under Article 106 (6) of the Constitution. The amount to be transferred depends on the local multipliers imposed 
on the trade tax and the location of a particular municipality (whether it is located in a new or an old state). Moreover, since 1st July 2009, the states have been participating in the revenues from the motor vehicle tax collected by Federation.

The share of a particular municipality in the revenue from income taxes depends on the taxable income and the tax paid by its inhabitants in a statutorily defined year. In the calculation of the revenues from the aforementioned taxes received by a municipality and in order to equalise the differences between municipalities whose inhabitants generate high income and those whose inhabitants generate low income in the case of each taxpayer only income up to a certain level is taken into account. The amount used in the calculation is 35,000 euros, in the case of individual tax settlement, and 70,000 euros, in the case of joint tax declaration (Gemeindeanteil, 2014, p. 21).

The apportionment of the revenues from value added tax is extremely complicated due to several amendments made in 1998 (implementation of the compensation for the abolition of the trade tax on business capital that accrued to the municipalities) and in 2007 (increase of the standard VAT rate) (Englisch \& Tappe, 2011, p. 285). When distributing the municipalities share in the revenues from value added tax amongst particular municipalities, the following elements are taken into account (in statutorily regulated proportions): the revenue from the trade tax, the number of employed obliged to pay insurance contributions, the amount of wages paid from which social insurance contributions must be made.

\section{Local Tax Authority and the Tax Revenue Sharing Mechanism in Poland}

Unlike in Germany, in Poland the provisions of the Constitution do not regulate in detail the scope of taxing power of public finance subsectors (the Constitution of the Republic of Poland of 2 April 1997; Konstytucja Rzeczypospolitej Polskiej z dnia 2 kwietnia 1997 roku). Article 16(2) of the Constitution includes, however, the principle of independence of local selfgovernments. In compliance with this principle local self-government units participate in exercising public power and are obliged to perform public tasks assigned to them on its own behalf and responsibility. The execution of these tasks is possible thanks to local self-governments' share in public revenue, including, according to Article 167(2) of the Constitution, their own revenues, general subsidies and specific grants designated from the state budget. 
In Poland competences in the field of tax law-making are vested in the central government. The authority equipped with the power to enact tax law is Parliament. In principle, the units of local self-government and their organs do not have the power to make tax law. However, under Article 168 of the Constitution the units of local self-government have the right to establish the rates of local taxes and charges in compliance with statutory regulated rules. As far as municipalities (gminy) are concerned, their competences with respect to tax law are implemented primarily by means of tax resolutions adopted by the municipal council (Popławski, 2009, p. 40).

The provisions of the Local Taxes and Fees Act of 12 January 1991 (Ustawa $z$ dnia 12 stycznia 1991 roku) entitle the municipal councils to determine the rates of real estate tax, motor vehicle tax, market duty, visitor's and resort duties, as well as the duty on dog owners. The rates may not exceed the upper limits specified in the statute. Municipal councils also have the right to determine the rules for the collection and time of payment of these taxes and duties, and to introduce tax deductions and exemptions. Moreover under Article 6(3) of the Farm Tax Act of 15 November 1984 (Ustawa $z$ dnia $z$ dnia 15 listopada 1984 roku), municipal councils may influence the amount of the farm tax by reducing the purchase prices of rye taken as a basis for calculating the tax, and - on the basis of Article 4(5) of the Forest Tax Act - influence the amount of forest tax by reducing the average selling price of wood taken as the basis for calculating the forest tax (the Act of 30 October 2002; Ustawa z dnia 30 października 2002 roku).

Most of the taxes in Poland constitute the source of revenue for the state budget. They include: value added tax, the excise duty on the following products: alcoholic beverages, tobacco products, energy and electricity, passenger cars, the gambling tax, flat-rate tax on registered income, tax on sale of securities, flat-rate tax on income of the clergy and the mineral extraction tax. The Polish tax system does not allow for any taxes which would constitute revenues of the districts (counties; powiaty) or regions (provinces; województwa samorzadowe). The sources of revenue for municipalities, on the other hand, are such taxes as: the real estate tax, farm tax, forest tax, motor vehicle tax, gift and inheritance tax, tax on civil law transactions and the fixed sum tax on the business activity of individuals (so called tax card assessment). Apart from that, the following duties also contribute to the municipalities' budgets: the stamp duty, market duty, visitor's and resort duty, duty on dog owners and a share in the mineral exploitation duty.

Local taxes are administered by the local authorities: the village head, the mayor, or the president. The only exceptions are: the gift and inher- 
itance tax, the tax on civil law transactions and the fixed sum tax on business activity of individuals, which constitute the source of revenue for municipalities but are administered by the central government authorities, i.e. the heads of tax offices. All other taxes are administered centrally.

In Poland personal and corporate income taxes are shared taxes, i.e. revenues from them are distributed amongst the state, regions, districts and municipalities. The share of public finance subsectors in revenue from these taxes is presented in Table 2 .

Table 2. Statutory share of public finance subsectors in revenues from shared taxes in Poland

\begin{tabular}{lccccc}
\hline \multirow{2}{*}{$\begin{array}{c}\text { Type } \\
\text { of tax }\end{array}$} & Year & $\begin{array}{c}\text { State } \\
\text { (budżet państwa) }\end{array}$ & $\begin{array}{c}\text { Regions } \\
\text { (województwa) }\end{array}$ & $\begin{array}{c}\text { Districts } \\
\text { (powiaty) }\end{array}$ & $\begin{array}{c}\text { Municipalities } \\
\text { (gminy) }\end{array}$ \\
\hline $\begin{array}{l}\text { Personal } \\
\text { income } \\
\text { tax }\end{array}$ & $1999-2003$ & 69.90 & 1.50 & 1.00 & 27.60 \\
\hline & 2004 & 50.64 & 1.60 & 8.42 & $39.34^{*}$ \\
\hline $\begin{array}{l}\text { Corporate } \\
\text { income } \\
\text { tax }\end{array}$ & since 2005 & 48.81 & 1.60 & 10.25 & $39.34^{*}$ \\
\cline { 2 - 6 } & $1999-2003$ & 94.50 & 0.50 & 0.00 & 5.00 \\
\cline { 2 - 6 } & $2004-2007$ & 75.99 & 15.90 & 1.40 & 6.71 \\
\hline
\end{tabular}

* The share of the municipalities in the revenues from personal income tax decreases by the number of percentage points equal to the product of 3.81 of the percentage point of the index calculated for the whole country. The index rate is established by dividing the number of inhabitants admitted to residential homes before 1st January 2004, as of 30th June of the base year, by the number of inhabitants admitted by 1 st January 2004, as of 31st December 2003. The participation share of municipalities in the revenues from the personal income tax was $35.72 \%$ in 2004 , in $2005-35.61 \%$, in $2006-35.95 \%$, in $2007-36.22 \%$, in $2008-36.49 \%$, in $2009-36.72 \%$, in $2010-36.94 \%$, in $2011-37.12 \%$, in 2012 $-37.26 \%$, in $2013-37.42 \%$, in $2014-37.53$.

Source: Jastrzębska (2012, p. 114).

In compliance with Article 9 of the Act of 13th November 2003 on the Revenues of Local Self-Government Units (Ustawa $z$ dnia 13 listopada $2003 \mathrm{roku}$ ), the amount of a municipality's share in the revenue from personal income tax is calculated by multiplying the total amount of the revenue from this tax by 0.3934 and an index equal to the share due in the year preceding the base year of the personal income tax from persons resident in a given municipality, as the total amount of the tax to be paid by all taxpayers in the same year. In the case of a district, the amount of its share in the revenue from personal income tax is calculated by multiplying the total amount of the revenues from personal income tax by 0.1025 and an index equal to the share of the personal income tax due in the year preceding the base year of the personal income tax from persons resident in a given district, as the total amount of the tax to be paid in the same year. In the case 
of regions, on the other hand - this share is calculated by multiplying the total amount of the revenue from this tax by 0.0160 and an index equal to the share of the personal income tax from persons resident in a given region due in the year preceding the base year, as the total amount of the tax to be paid in the same year. These indices are established on the basis of statistics from tax returns submitted on the amount of income and annual tax calculations made by taxpayers as of $15^{\text {th }}$ September of the base year.

The amounts of shares of regions, districts and municipalities in the revenue from corporate income tax depends on the number of taxpayers having registered offices or facilities in their territories. If a corporate income taxpayer has a facility on the territory of a local self-government unit other than the one where its registered office is located, part of the revenues from the share in the revenue from this tax is transferred to the budget of the local self-government unit in which this facility operates, proportionally to the number of people employed there under a contract of employment. In the case of a corporate income taxpayer conducting business through a foreign facility located in the Republic of Poland, part of the revenue from the share in the revenue from this tax is transferred to the budget of the local self-government unit where the employers of this taxpayer or of his foreign facility perform work under a contract of employment, proportionally to the number of people employed by him or this foreign facility located in the Republic of Poland.

\section{Tax Revenue Assignment in Germany and Poland in the Years 2009-2013}

Both in Germany and in Poland taxes constitute an important source of the public revenue. However, their significance varies considerably for different public finance subsectors (Taxation trends, 2014, pp. 203-208). In Germany, the share of tax revenue in the total revenue of the Federation and the states in 2009-2013 was similar (Table 5). The basic source of tax revenue for both the Federation and the states are shared taxes, which constitute about $74 \%$ of the total tax revenue of the public finance sector (without taking into account the subsector of social insurance) and about $80 \%$ of the tax revenue both for the Federation and the states. From Table 3 it can be concluded that the dominant source of revenue for the Federation is the value added tax. This is related not only to its collection efficiency but also to a considerable statutory share of the Federation in the revenue from this tax. A significant source of revenue for the Federation are also excise duties, the revenue from which account for over $20 \%$ of its tax reve- 


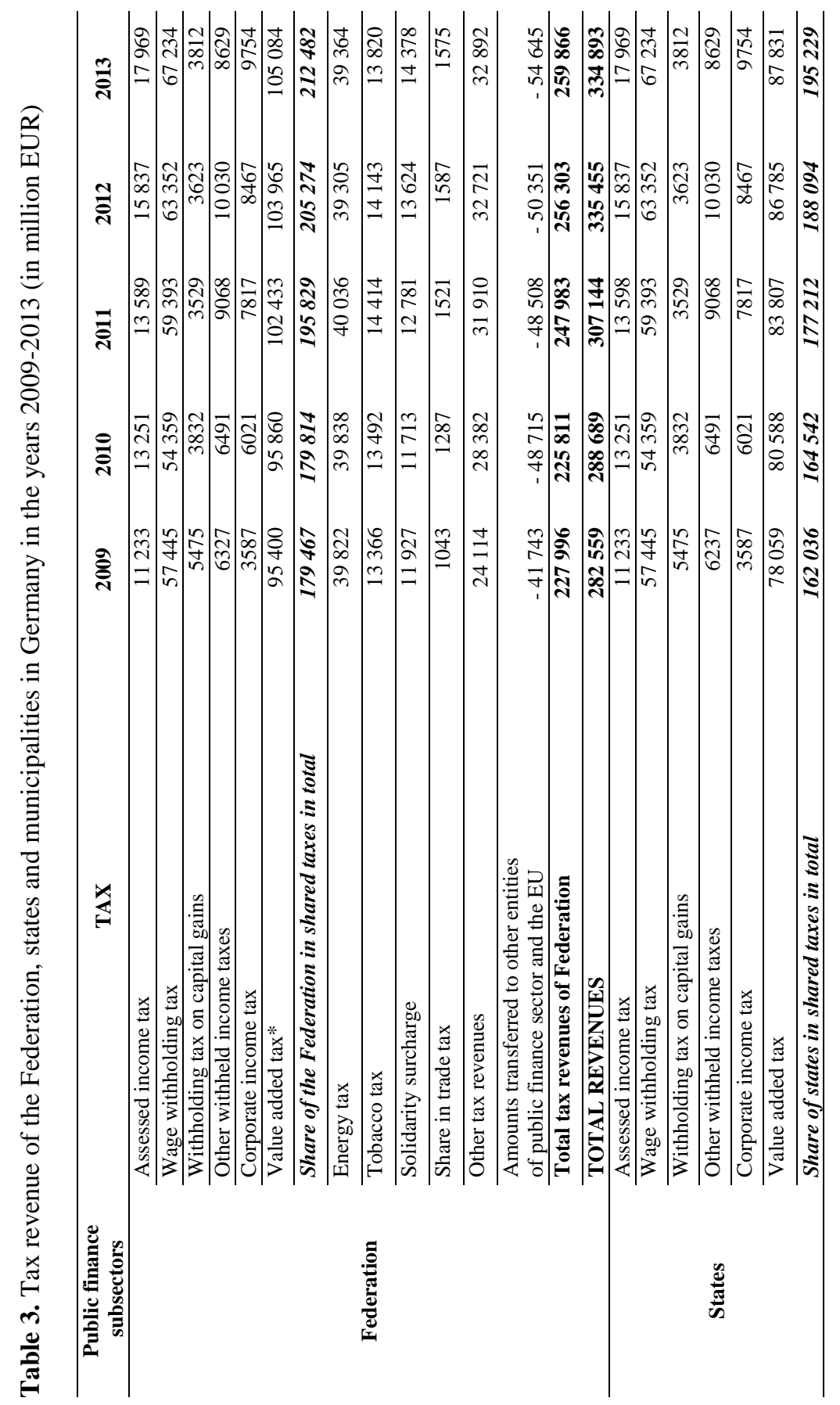




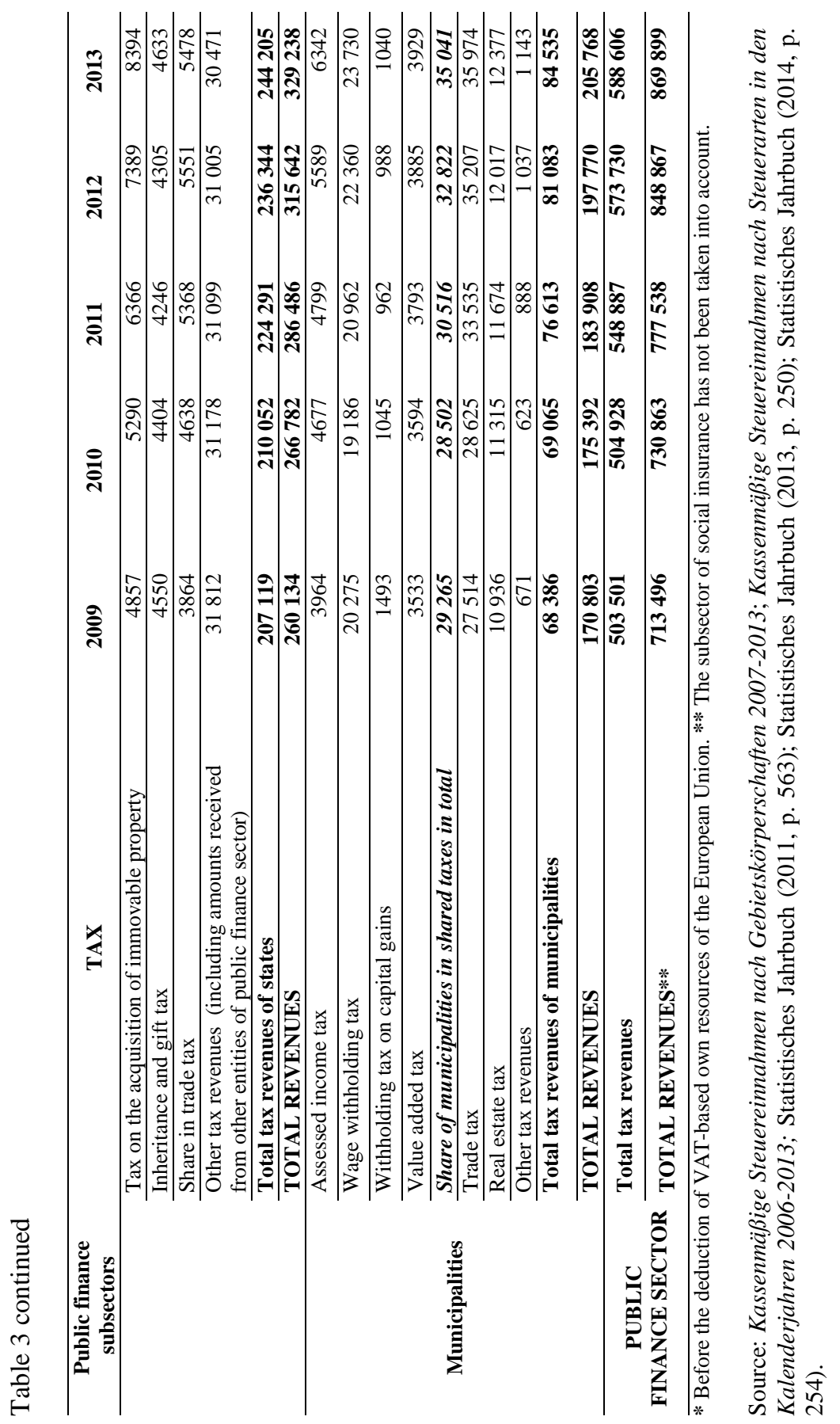




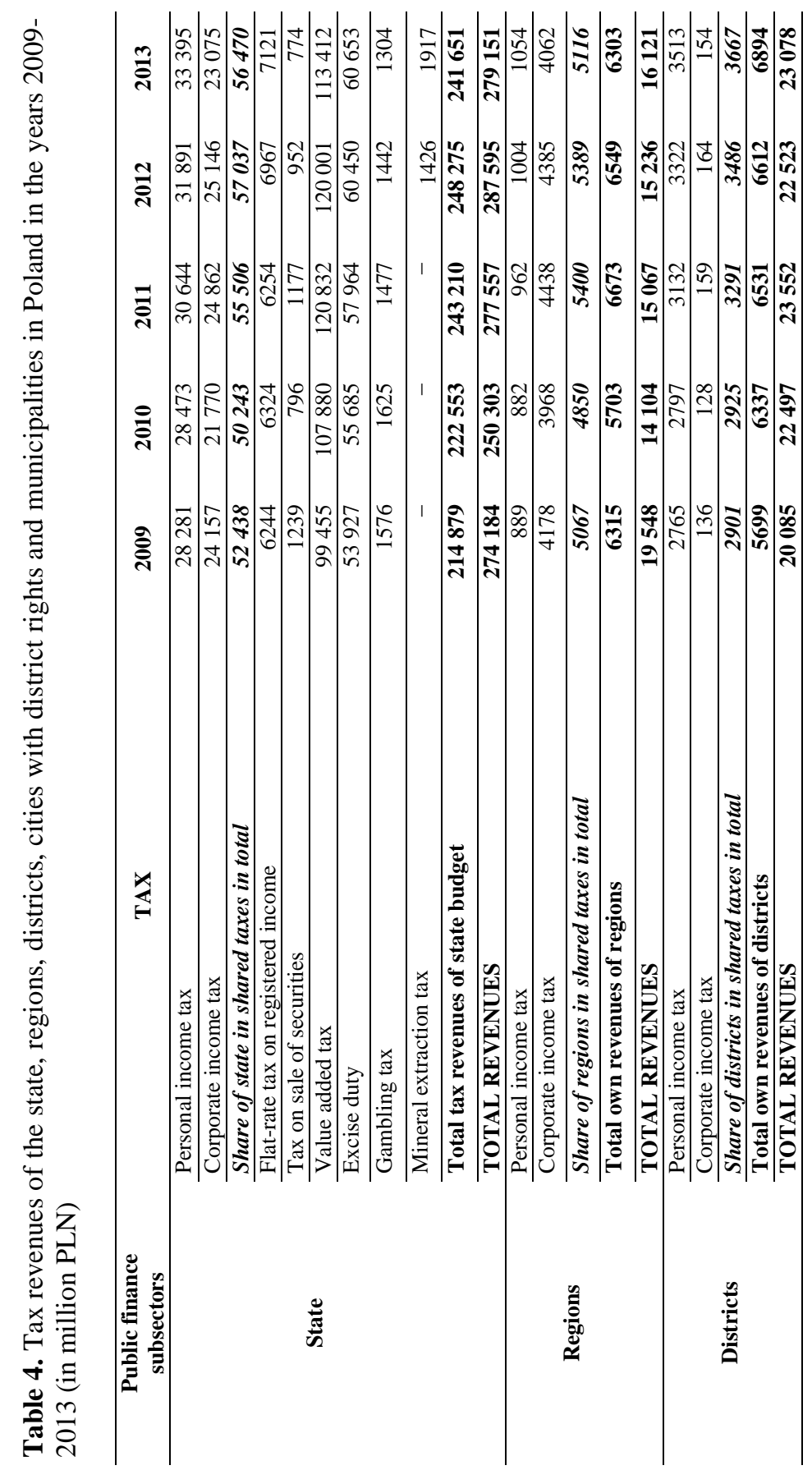




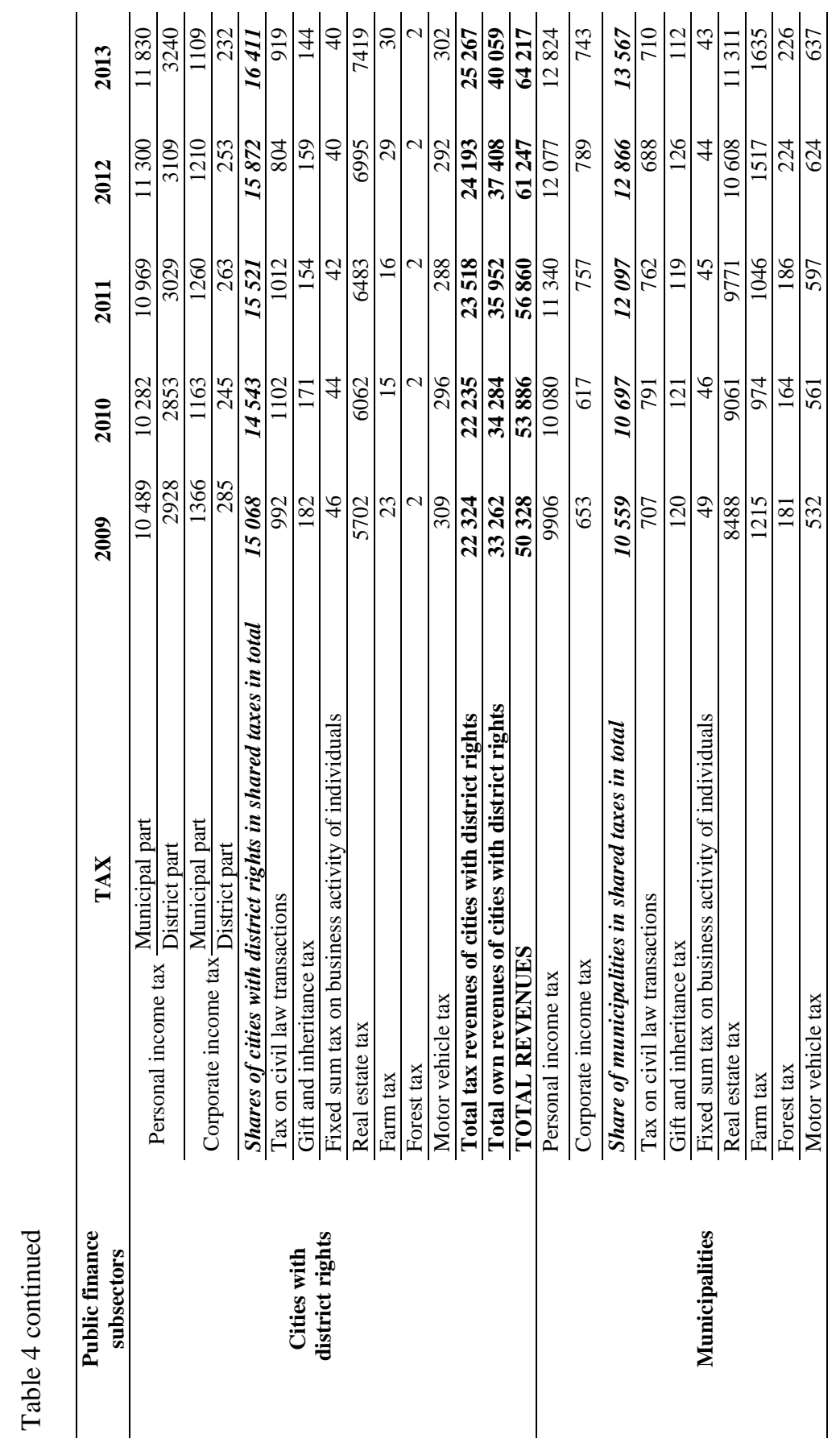




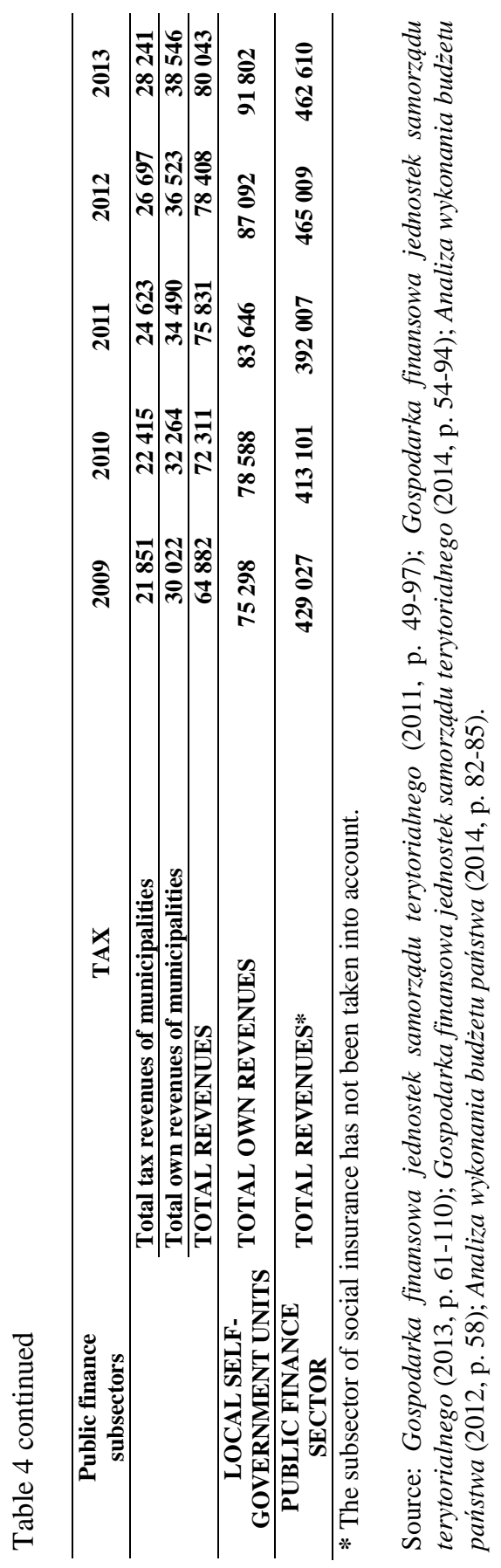


nue. The most efficient are the excise duties imposed on energy and tobacco products.

The tax revenue of the Federation are reduced by amounts transferred to the budgets of other entities of the public finance sector and the budget of the European Union. The amounts deducted from these revenues include their own resources of the EU - both VAT- and GNI-based, as well as supplementary federal grants (Bundesergänzungszuweisungen). Moreover the Federation gives part of its revenue from the taxation of mineral oil to the states under Article 5 of the Regionalization Act (Regionalisierungsgesetz vom 27. Dezember 1993). These resources are used to finance inter alia railway transport. The federal budget also pays the states a percentage of revenue from the motor vehicle tax. The states' share in the revenue from shared taxes and tax revenue in total is slightly lower than the share of the Federation (from 3 to 5 percentage points). The states obtain their own tax revenues mainly from the tax on the acquisition of immovable property, inheritance and gift tax and the excise duty on beer. However, the largest revenue of the states comes from their share in value added tax.

Table 5. Shares of Federation, states and municipalities in tax revenues and revenues from shared taxes in Germany in the years 2009-2013

\begin{tabular}{lcccc}
\hline \multicolumn{1}{c}{ Specification } & Years & Federation & States & Municipalities \\
\hline \multirow{3}{*}{$\begin{array}{l}\text { Share of revenues } \\
\text { from shared taxes in tax } \\
\text { revenues (\%) }\end{array}$} & 2009 & 78.71 & 78.23 & 42.79 \\
\cline { 2 - 5 } & 2010 & 79.63 & 78.33 & 41.27 \\
\cline { 2 - 5 } & 2011 & 78.97 & 79.01 & 39.83 \\
\cline { 2 - 5 } & 2012 & 80.09 & 79.58 & 40.48 \\
\cline { 2 - 5 } & 2013 & 81.77 & 79.94 & 41.45 \\
\cline { 2 - 5 } & 2009 & 80.69 & 79.62 & 40.04 \\
\cline { 2 - 5 } $\begin{array}{l}\text { Share of tax revenues in total } \\
\text { revenues (\%) }\end{array}$ & 2010 & 78.22 & 78.74 & 39.38 \\
\cline { 2 - 5 } & 2011 & 80.74 & 78.29 & 41.66 \\
\cline { 2 - 5 } & 2013 & 76.40 & 74.88 & 41.00 \\
\hline \multirow{3}{*}{$\begin{array}{l}\text { Share of particular public } \\
\text { finance subsectors in reve- } \\
\text { nues from shared taxes (\%) }\end{array}$} & 2009 & 48.41 & 74.17 & 41.08 \\
\cline { 2 - 5 } & 2010 & 48.23 & 44.70 & 7.89 \\
\hline & 2012 & 48.16 & 43.91 & 7.64 \\
\hline \multirow{3}{*}{$\begin{array}{l}\text { Share of particular public } \\
\text { finance subsectors in tax } \\
\text { revenues (\%) }\end{array}$} & 2013 & 47.99 & 44.09 & 7.73 \\
\cline { 2 - 5 } & 2009 & 45.28 & 41.14 & 13.92 \\
\hline & 2010 & 44.72 & 41.60 & 13.68 \\
\hline & 2012 & 45.18 & 40.86 & 13.96 \\
\hline
\end{tabular}

Source: Data from Table 3. 
In the case of municipalities, both the proportion of the revenue from the shared taxes in the total tax revenue and of the total tax revenue in the total revenues is lower than in the case of the Federation and the states. The share of municipalities in the revenues from the shared taxes is insignificant and does not exceed $8 \%$. The budgets of municipalities are supplied mostly by subsidies and grants. The largest tax revenue sources of municipalities are their share in the wage withholding tax and the trade tax.

In Poland the share of tax revenue in public revenue is relatively high in the case of the state budget (Table 6). The most important sources of tax revenue are value added tax and the excise tax, the revenues from which account for about $73 \%$ of all the tax revenue of the state budget.

Table 6. Shares of the state, regions, districts, cities with district rights and municipalities in tax revenues and revenues from shared taxes in Poland in the years 2009-2013

\begin{tabular}{|c|c|c|c|c|c|c|}
\hline Specification & Years & State & Regions & Districts & $\begin{array}{c}\text { Cities with } \\
\text { district } \\
\text { rights }\end{array}$ & $\begin{array}{c}\text { Municipali- } \\
\text { ties }\end{array}$ \\
\hline \multirow{5}{*}{$\begin{array}{l}\text { Share of revenues } \\
\text { from shared taxes } \\
\text { in tax revenues } \\
(\%)\end{array}$} & 2009 & 24.40 & 100.00 & 100.00 & 67.50 & 48.32 \\
\hline & 2010 & 22.58 & 100.00 & 100.00 & 65.41 & 47.72 \\
\hline & 2011 & 22.82 & 100.00 & 100.00 & 66.00 & 49.13 \\
\hline & 2012 & 22.97 & 100.00 & 100.00 & 65.61 & 48.19 \\
\hline & 2013 & 23.37 & 100.00 & 100.00 & 64.95 & 48.04 \\
\hline \multirow{5}{*}{$\begin{array}{l}\text { Share of tax } \\
\text { revenues in total } \\
\text { revenues (\%) }\end{array}$} & 2009 & 78.37 & 25.92 & 14.44 & 44.36 & 33.68 \\
\hline & 2010 & 88.91 & 34.39 & 13.00 & 41.26 & 31.00 \\
\hline & 2011 & 87.63 & 35.84 & 13.97 & 41.36 & 32.47 \\
\hline & 2012 & 86.33 & 35.37 & 15.48 & 39.50 & 34.05 \\
\hline & 2013 & 86.57 & 31.74 & 15.89 & 39.35 & 35.28 \\
\hline \multirow{5}{*}{$\begin{array}{l}\text { Share of particular } \\
\text { public finance sub- } \\
\text { sectors in revenues } \\
\text { from shared taxes } \\
(\%)\end{array}$} & 2009 & 60.95 & 5.89 & 3.37 & 17.51 & 12.28 \\
\hline & 2010 & 60.35 & 5.83 & 3.51 & 17.47 & 12.84 \\
\hline & 2011 & 60.45 & 5.88 & 3.58 & 16.90 & 13.19 \\
\hline & 2012 & 60.26 & 5.69 & 3.68 & 16.78 & 13.59 \\
\hline & 2013 & 59.30 & 5.37 & 3.85 & 17.23 & 14.25 \\
\hline \multirow{5}{*}{$\begin{array}{l}\text { Share of } \\
\text { particular public fi- } \\
\text { nance sub- } \\
\text { sectors in tax } \\
\text { revenues }(\%)\end{array}$} & 2009 & 80.47 & 1.90 & 1.09 & 8.36 & 8.18 \\
\hline & 2010 & 80.93 & 1.76 & 1.06 & 8.09 & 8.16 \\
\hline & 2011 & 81.06 & 1.80 & 1.10 & 7.84 & 8.20 \\
\hline & 2012 & 80.60 & 1.75 & 1.13 & 7.85 & 8.67 \\
\hline & 2013 & 79.51 & 1.68 & 1.21 & 8.31 & 9.29 \\
\hline
\end{tabular}

Source: Data from Table 4. 
The percentage of shared taxes in this budget is definitely lower than in Germany. It must be also emphasized that, unlike Germany, in Poland the value added tax is not a shared tax. At the same time, the proportion of income taxes, which are shared in the tax revenue of Federation in Germany was, in the years 2009-2013, 12.5 to 18.0 percentage points higher than the proportion of income taxes in the tax revenue of the state budget in Poland; one of the reasons is the higher collection efficiency of German income taxes. The regional level of local self-government in Poland does not have any tax revenue; it has a share of the shared taxes, but they are insignificant. In the case of districts, which also do not have their own tax revenue, the proportion of revenue from the shared taxes in the total is even lower.

Municipalities and cities with district rights have their own tax revenue, which include also shares in shared taxes. It must be noted that the share of municipalities and cities with district rights in revenues from personal income tax is relatively high. As a result municipalities in Poland are entitled to a higher share in revenue from shared taxes than in Germany. The situation is different in the case of the share of particular levels of the public finance sector in tax revenue. In the case of German municipalities this share is higher than in Poland. This is a result of a higher collection efficiency of local taxes in Germany. One of the most important sources of tax revenue for German municipalities is the trade tax. The most efficient source of tax revenues for Polish municipalities is the real estate tax.

\section{Conclusions}

Taxing powers of German and Polish sub-central government units differ considerably. These differences are especially visible when comparing tax competences of regions and districts in Poland and the states in Germany. It must be added that the sources of revenue and their structure are adjusted to a greater or lesser extent to the need for public resources and to the public tasks performed. Due to systemic differences between the two countries the tasks of Polish regions and districts are different from those of German states.

States in Germany have relatively broad taxing powers. The Constitution provides them with the power to legislate with regard to local taxes on consumption and expenditures so long and insofar as such taxes are not substantially similar to taxes regulated by federal law. German states receive revenue from selected wealth and sales taxes. Moreover the Federation and the states have a similar level of revenue from shared taxes, which 
results in a comparative level of their shares in tax revenue. In Poland, regions and districts have no legislative powers with respect to tax law. They do not generate any of their own tax revenue but do participate in the revenue from the shared taxes. However their share in tax revenue that include only the revenue from shared taxes is insignificant. Therefore, their most basic sources of funding are general subsidies and specific grants.

The taxing power of municipalities is significantly restricted both in Germany and in Poland. The legislative powers of municipalities with respect to tax law are limited to deciding the rates of some local taxes (only within statutory restrictions). Municipalities have no power to independently impose taxes and shape the elements of the overall tax design. German municipalities are entitled to a lower share in the revenue from shared taxes than in Poland but their share in the tax revenue of the public finance sector is still higher. A significant part of the tax revenue of municipalities in Germany comes from a relatively efficient trade tax.

A comprehensive evaluation of the scope of independence of local selfgovernment units in both countries would require the taking into account of not only the level and structure of their tax revenue but also their revenue from other sources and the level and structure of their expenditure, taking into account tasks performed at various levels of the public finance sector.

\section{References}

Analiza wykonania budżetu państwa i założeń polityki pieniężnej w 2011 roku (2012). Warszawa: Najwyższa Izba Kontroli.

Analiza wykonania budżetu państwa i założeń polityki pieniężnej w 2013 roku (2014). Warszawa: Najwyższa Izba Kontroli.

Blöchliger, H., \& Nettley M. (2015). Sub-central Tax Autonomy: 2011 Update. OECD Working Papers on Fiscal Federalism, 20. DOI: http://dx.doi.org/10. 1787/5js4t79sbshd-en.

Boadway, R., \& Shah, A. (2009). Fiscal Federalism: Principles and Practice of Multiorder Governance. Cambridge: Cambridge University Press. DOI: http://dx.doi.org/10.1017/CBO9780511626883.

Bönke, T., Jochimsen, B., \& Schröder, C. (2013). Fiscal Federalism and Tax Administration - Evidence From Germany. DIW Berlin Discussion Paper. 1307. DOI: http://dx.doi.org/10.2139/ssrn.2294400.

Das bundesstaatliche Finanzausgleich (2014). Stuttgart: Baden-Württemberg Ministerium für Finanzen und Wirtschaft.

Englisch, J., \& Tappe, H. (2011). The Federal Republic of Germany. In G. Bizioli \& C. Sacchetto (Eds.). Tax Aspects of Fiscal Federalism: a Comparative Analysis. Amsterdam: International Bureau of Fiscal Documentation. 
Finanzverwaltungsgesetz in der Fassung der Bekanntmachung vom 4. April 2006 (BGB1. I S. 846, 1202), das zuletzt durch Artikel 18 des Gesetzes vom 25. Juli 2014 (BGB1. I S. 1266) geändert worden ist.

Finanzausgleichsgesetz in der Fassung der Bekanntmachung vom 20. Dezember 2001 (BGB1. I S. 3955, 3956), das zuletzt durch Artikel 2 des Gesetzes vom 15. Juli 2013 (BGBl. I S. 2401) geändert worden ist.

Der Gemeindeanteil an der Einkommensteuer in der Gemeindefinanzreform. (2014). Berlin: Bundesministerium der Finanzen.

Gospodarka finansowa jednostek samorządu terytorialnego 2010 (2011). Warszawa: Główny Urząd Statystyczny.

Gospodarka finansowa jednostek samorządu terytorialnego 2012 (2013). Warszawa: Główny Urząd Statystyczny.

Gospodarka finansowa jednostek samorządu terytorialnego 2013 (2014). Warszawa: Główny Urząd Statystyczny.

Grundgesetz für die Bundesrepublik Deutschland in der im Bundesgesetzblatt Teil III, Gliederungsnummer 100-1, veröffentlichten bereinigten Fassung, das zuletzt durch Artikel 1 des Gesetzes vom 11. Juli 2012 (BGBl. I S. 1478) geändert worden ist.

Jastrzębska, M. (2012). Finanse jednostek samorządu terytorialnego. Warszawa: Wolters Kluwer Polska.

Kassenmäßige Steuereinnahmen nach Gebietskörperschaften 2007-2013. Retrieved form www.bundesministerium.de (02.01.2015).

Kassenmäßige Steuereinnahmen nach Steuerarten in den Kalenderjahren 20062013. Retrieved form www.bundesministerium.de (02.01.2015).

Kedar, O. (2009). Voting for Policy, not Parties: How Voters Compensate for Power Sharing. Cambridge: Cambridge University Press. DOI: http://dx.doi. org/10.1017/CBO9780511657481.

Konstytucja Rzeczypospolitej Polskiej z dnia 2 kwietnia 1997 roku, tj. Dz. U. z 1997 r. Nr 78, poz. 483, z późn. zm.

Oates, W. E. (2008). On The Evolution of Fiscal Federalism: Theory and Institutions. National Tax Journal, 61(2).

Popławski, M. (2009). Wymiar i pobór podatków i opłat lokalnych. Bydgoszcz: Wydawnictwo Temida 2.

Regionalisierungsgesetz in der Fassung der Bekanntmachung vom 27. Dezember 1993 (BGB1. I S. 2378, 2395), das zuletzt durch Artikel 4 des Gesetzes vom 14. Dezember 2012 (BGB1. I S. 2598) geändert worden ist.

Statistisches Jahrbuch 2010 für die Bundesrepublik Deutschland (2011). Wiesbaden: Statistisches Bundesamt Deutschland.

Statistisches Jahrbuch 2012 für die Bundesrepublik Deutschland (2013). Wiesbaden: Statistisches Bundesamt Deutschland.

Statistisches Jahrbuch 2013 für die Bundesrepublik Deutschland (2014). Wiesbaden: Statistisches Bundesamt Deutschland.

Taxation trends in the European Union. Data for the EU Member States, Iceland and Norway. (2014). Luxembourg: Publications Office of the European Union. DOI: http://dx.doi.org/10.2778/33696. 
Ulbricht, A. (2008). The Decentralisation of Tax Administration in Germany: Consequences. In N. Bosch \& J. M. Durán (Eds.). Fiscal Federalism and Political Decentralisation - Lessons from Spain, Germany and Canada. Cheltenham: Edward Elgar Publishing.

Ustawa z dnia z dnia 15 listopada 1984 roku o podatku rolnym, tj. Dz. U. z 2013 r. poz. 1381, z 2014 r. poz. 40.

Ustawa z dnia 12 stycznia 1991 roku o podatkach i opłatach lokalnych, tj. Dz. U. z 2010 r. Nr 95, poz.613, z późn. zm.

Ustawa z dnia 30 października 2002 roku o podatku leśnym, tj. Dz. U. z 2013 r. poz. 465 .

Ustawa z dnia 13 listopada 2003 roku o dochodach jednostek samorządu terytorialnego, tj. Dz. U. z 2014 r. poz. 1115, 1574, 1644.

Zerlegungsgesetz in der Fassung der Bekanntmachung vom 6. August 1998 (BGB1. I S. 1998), das zuletzt durch Artikel 12 des Gesetzes vom 25. Juli 2014 (BGB1. I S. 1266) geändert worden ist. 